NBER WORKING PAPER SERIES

\title{
BIOMEDICAL ACADEMIC ENTREPRENEURSHIP \\ THROUGH THE SBIR PROGRAM
}

\author{
Andrew A. Toole \\ Dirk Czarnitzki \\ Working Paper 11450 \\ http://www.nber.org/papers/w11450

\section{NATIONAL BUREAU OF ECONOMIC RESEARCH 1050 Massachusetts Avenue Cambridge, MA 02138} \\ June 2005
}

We are grateful to Wesley Cohen and Josh Lerner for helpful comments and to Thorsten Doherr for providing his text field search engine. Morever, we thank the participants of following conferences/workshops for fruitful discussions: Innovation Seminar at UC Berkeley, CA; NBER Academic Science \& Entrepreneurship Conference, Santa Fe, NM; International Industrial Organization Conference, Atlanta, GA. The views expressed herein are those of the author(s) and do not necessarily reflect the views of the National Bureau of Economic Research.

(C2005 by Andrew A. Toole and Dirk Czarnitzki. All rights reserved. Short sections of text, not to exceed two paragraphs, may be quoted without explicit permission provided that full credit, including $\mathbb{C}$ notice, is given to the source. 
Biomedical Academic Entrepreneurship Through the SBIR Program

Andrew A. Toole and Dirk Czarnitzki

NBER Working Paper No. 11450

June 2005

JEL No. O38, O31, G38, M13, C25

\section{ABSTRACT}

This paper considers the U.S. Small Business Innovation research (SBIR) program as a policy fostering academic entrepreneurship. We highlight two main characteristics of the program that make it attractive as an entrepreneurship policy: early-stage financing and scientist involvement in commercialization. Using unique data on NIH supported biomedical researchers, we trace the incidence of biomedical entrepreneurship through SBIR and describe some of the characteristics of these individuals. To explore the importance of early-stage financing and scientist involvement, we complement our individual level data with information on scientist-linked and non-linked SBIR firms. Our results show that the SBIR program is being used as a commercialization channel by academic scientists. Moreover, we find that the firms associated with these scientists perform significantly better than other non-linked SBIR firms in terms of follow-on venture capital funding, SBIR program completion, and patenting.

Andrew A. Toole

Rutgers University

Department of Ag, Food, and Resource

Economics

55 Dudley Road

New Brunswick, NJ 08901

toole@aesop.rutgers.edu
Dirk Czarnitzki

Katholieke Universiteit Leuven and ZEW Mannheim

Department of Applied Economics and Steunpunt O\&O Statistieken

Dekenstraat 2

3000 Leuven

BELGIUM

dirk.czarnitzki@econ.kuleuven.ac.be 


\section{Introduction}

The U.S. Small Business Innovation Research (SBIR) Program was established in 1982 to address concerns about the competitiveness of U.S. industry. The legislation aims to increase the share of procurement contracts going to small firms from the largest federal R\&D agencies and to increase commercialization of federally funded research. In this paper we suggest that the SBIR program also fosters academic entrepreneurship. Except for some initial work by Audretsch et al. (2002b), this perspective of the SBIR program has been largely ignored.

There are two main characteristics of the program and make it attractive as a policy for academic entrepreneurship. First, since most university-based technologies are early-stage and characterized by a high degree of technical and market uncertainty, external financing is difficult to obtain from private sources like venture capital (Bhide, 2000). Using a real options framework, we argue that the SBIR program will fund promising but unproven technologies earlier than private investors as a result of both the program's structure and selection process. This creates a financial incentive for academic entrepreneurs to pursue commercialization through the SBIR program as well as the possibility for follow-on private investors to increase their returns by leveraging their investment on the initial public funding. In earlier work, Lerner (1999) points out that participation in the SBIR program may have a "certification" effect that increases the chances for obtaining follow-on private investment. The real options framework sheds light on one mechanism underlying certification.

Second, the SBIR program requires academic entrepreneurs to commit "full-time" to the commercialization process throughout the duration of the project. In complex technological fields, like biomedicine, there is mounting evidence that faculty involvement in the commercialization of university-based technologies is important for success. In a stream of research focusing on "star" scientists in biotechnology, Zucker et al. (1998a, 1998b, 2002) point out that scientific discoveries embody tacit knowledge that can only be communicated through "bench-level" interaction. Their work suggests that firms are more successful when discovery scientists are involved in the development of their ideas for commercial application. Using a survey of university technology transfer offices, Thursby et al. (2001) find that faculty-inventor involvement is important for commercial development after licensing. Case study research by 
Lowe (2001) and Murray (2004) also supports this finding, particularly in biomedical discoveries.

For those discovery scientists willing to devote full-time to commercialization, the financial gain made possible by participation in the program should motivate university researchers to commercialize their discoveries through SBIR. To find out if SBIR is used as a commercialization channel, however, requires systematic data tracking individual scientists as they venture from research into business. The SBIR program provides a unique opportunity to track these individuals since many of the principal investigators (PIs) on SBIR projects were researchers at universities and other non-profit research institutions. Focusing on biomedical scientists, we use data on individual researchers to investigate the incidence of academic entrepreneurship from the beginning of the SBIR program up to 1996. Moreover, we are able to provide some descriptive information about SBIR academic entrepreneurs such as whether these individuals are "star" biomedical scientists or not.

In addition to documenting entrepreneurship by individual scientists, we collect firm level data to investigate the impact that academic entrepreneurs have on the performance of SBIR firms. The literature suggests that discovery scientists, particularly star scientists, possess valuable specialized knowledge, network contacts, or reputations. If these capabilities confer advantages, SBIR firms "linked" to academic entrepreneurs should perform better than similar "non-linked" SBIR firms. In our empirical work, we relate three measures of firm performance to the presence of an academic entrepreneur and their status as a star researcher: the likelihood of follow-on private venture capital investment; the likelihood of "completing" the SBIR program; and firm patenting activity.

Consistent with the idea that the SBIR program fosters academic entrepreneurship, we find that the program is used as a commercialization channel by biomedical researchers. Academic entrepreneurs are a relatively small group among SBIR PIs but their numbers grew steadily since 1991 . Our indicator of academic achievement shows that $14 \%$ of these entrepreneurs are star scientists. As regards firm performance, both the presence of an academic entrepreneur and their star status significantly increase the firm's likelihood for follow-on venture capital investment. Scientist-linked SBIR firms also have a greater probability of completing the SBIR program and patent more. While these results shed new light on aspects of the SBIR program and its role as an academic entrepreneurship policy, our empirical tests should 
be viewed as suggestive rather than definitive since our data do not allow us to address the endogeneity between firm quality before SBIR and the presence of an academic entrepreneur.

The rest of the paper proceeds as follows. The next section describes the background of the SBIR program and its role in funding early-stage technology companies. This section also develops our hypotheses in greater depth. Section III discusses the data and methodology. Section IV presents our results and concluding comments appear in section V.

\section{The SBIR Program and Its Role in Financing Early-stage Technology}

\section{$\underline{\text { SBIR Background }}$}

Created by the Small Business Innovation Development Act of 1982, the SBIR program made its first financial awards in 1983. The original legislation mandated that all federal agencies with an extramural research budget greater than $\$ 100$ million set aside $1.25 \%$ of these

funds for this program. ${ }^{1}$ After the program was reauthorized in 1992, the set-aside was increased to its current level of 2.5\%. The program is now authorized through September 30th, 2008.

The SBIR program has become the largest commercialization program focused on small firms in U.S. history. According to the Small Business Administration (SBA), the program awarded $\$ 8.6$ billion in direct subsidies between 1983 and 1996. Funds awarded under SBIR have generally grown each year because its budget is a fixed proportion of each agency's extramural R\&D budget. This has been especially true for the two largest SBIR agencies, the Department of Defense and the Department of Health and Human Services. Beginning in 1997, annual awards across all agencies exceeded $\$ 1$ billion and a recent figure from the National Research Council estimates the total value of awards made in 2003 to be over $\$ 1.6$ billion (NRC, 2004).

The SBIR program has eligibility requirements limiting which firms may apply as well as restricting the employment of SBIR principal investigators. The program is open to all for-profit firms that have 500 or fewer employees and are at least $51 \%$ owned by U.S. citizens. SBIR PIs are the scientific and technical project leaders and are the primary people who interact with the agency program administrators. To qualify as a PI, individuals must be employed "full-time" at the small business at the time of award and throughout the duration of the project. Full-time 
means at least $51 \%$ of the PI's time and precludes full-time employment at any other institution including universities and non-profit research institutions.

The legislation established three phases to the SBIR program. All applicants must start with a Phase 1 proposal. The Phase 1 project is intended to test the feasibility of a new idea. The feasibility study lasts from six to twelve months and the Phase 1 awards can be up to $\$ 100,000$. If the results of the feasibility study are favorable, firms may apply for a Phase 2 grant to move their idea into product development. The Phase 2 award is up to $\$ 750,000$ and lasts for a two-year period. Finally, there is a Phase 3 to the SBIR program. This is an unfunded phase in which companies are expected to commercialize their product or process. Sometimes agencies award non-SBIR funds to firms in Phase 3.

There are many differences across SBIR agencies in the focus and administration of the program. Agencies differ in the degree to which program announcements are targeted to specific mission-oriented needs. The U.S. Dept. of Defense and NASA represent the most targeted programs and the DHHS and NSF represent the least targeted. For those targeted programs, SBIR awards bring a relatively close working relationship with the agency. These agencies use the program as an extension of their procurement contracting process to smaller companies. On the other hand, agencies like the DHHS have broadly defined program announcements covering many scientific areas and they encourage investigator-initiated proposals. These agencies rely much more on external peer review versus internal administrative review to determine scientific and commercial merit. There are also differences in the technology areas funded by the agencies. While there is some overlap, the DHHS funds the dominant share of health-oriented projects.

\section{Academic Entrepreneurship and SBIR}

Academic entrepreneurship is a particular form of technology transfer. It takes place when researchers in universities and non-profit institutions decide to participate in the commercialization of a technology that originated or was substantially developed within their institutions. An academic entrepreneur is no longer just a scientific investigator but an active participant in business oriented functions. In its most extreme form, the academic entrepreneur actually leaves the non-profit research environment to pursue commercialization of the 
"university-based" technology full-time in the private sector by starting a firm or joining an existing firm.

With the exception of Audretsch et al. (2002b), the policy and academic literatures have not focused on SBIR as an incentive program inducing academic entrepreneurship but instead have focused on evaluating the impact of the SBIR program on project and firm performance measures. ${ }^{2}$ Audretsch and his coauthors suggest that the SBIR program induces scientists and engineers to change their career trajectories to pursue commercialization as a result of winning an SBIR award. Using 12 case studies and survey data from 20 SBIR participant firms in Indiana, they find that most firm founders came from universities. Over half of the survey respondents agreed that the SBIR award influenced their decision to start a new firm or continue the firm. Only $15 \%$ would have pursued other sources of financing to start their firm. They also find some limited evidence of a "demonstration effect" in which a scientist's decision to pursue commercialization through SBIR was influenced by observing the success of others.

Like Audretsch and his coauthors, we believe the SBIR program provides an incentive structure that fosters academic entrepreneurship. For full-time academic entrepreneurs, particularly those seeking to pursue commercialization through the formation of a new firm, we expect the SBIR program to be an attractive financing option relative to other sources. Its attractiveness will depend on, among other things, the entrepreneur's available financing options and the relative cost of SBIR funds.

Numerous studies both in the U.S. and abroad point out that the technologies discovered in research institutions are "embryonic" and characterized by a high degree of technical and market uncertainty. ${ }^{3}$ Investments required to commercialize these technologies share three basic characteristics. First, the investment is substantially sunk. That is to say, it is rarely possible to recoup much of the investment since most of the funds are used for follow-on research and development. Second, the investment opportunity is characterized by technical and market uncertainties that may diminish over time as information becomes available. Third, the opportunity to invest in university-based technologies is seldom completely dissipated away through competition among rivals.

These basic characteristics combine to create a positive option value for waiting to invest as described by the economic theory of investment under uncertainty (Dixit, 1992, and Pindyck, 1991). Their framework shows that it can be optimal for private investors like venture capitalists 
to wait instead of investing in university-based discoveries, even when the private net present value is positive. How long private investors choose to wait depends on the magnitude of the option value which, in turn, depends on the investor's patience and the degree of uncertainty characterizing the opportunity. Private investors will delay investment longer, the value of waiting increases, as the time to market for university discoveries increases. Shane (2004) and Lowe (2001) present case study evidence highlighting the short-term or "near market" preferences of venture capitalists based on the experiences of entrepreneurs commercializing discoveries from MIT and the campuses of the University of California. For instance, Lowe quotes an entrepreneur as saying, "Our technology was early-stage. We could only describe where we were going, but we didn't have any prototype to show (venture capitalists). They want to see that you're going to have a product soon." (Lowe, 2001, p. 199) Moreover, the value of waiting also increases as the degree of technical and/or market uncertainties increase. Among investment opportunities, early-stage university discoveries are among the most uncertain.

Even with efficient capital markets, the decision to wait by private investors creates an investment "timing gap" that impedes the commercialization of potentially valuable university discoveries. ${ }^{4}$ Taking the time preferences of investors as fixed, the only way to attract private investment for these university discoveries is to reduce the option value of waiting by reducing the degree of technical and/or market uncertainties. Unfortunately, neither individual faculty nor university technology transfer offices (TTOs) have any incentive to independently undertake the necessary steps required to reduce these uncertainties. Individual faculty members, who are motivated by scientific discovery and publication goals, are not professionally rewarded for spending time and money on commercialization activities. University TTOs focus on licensing discoveries and do not have the money or expertise to reduce technical or market uncertainties for their portfolio of invention disclosures. Consequently, there is a real possibility that many university discoveries will remain "on the shelf" - too early-stage for private investors and too commercial for the university.

Public programs like SBIR that fund early-stage university technologies may play a useful "bridging" role that addresses this timing gap. While the idea of SBIR playing a "gap filling" role is not new, the theoretical structure provided by the real options framework clarifies one role that public programs may play in fostering commercialization. According to this theory, public investors will invest earlier than private investors in university-based technologies if they 
see more immediate benefits such as knowledge spillovers prior to market introduction or if public investors put less weight on technical and market uncertainties when evaluating the investment option. Non-pecuniary benefits prior to market introduction may take the form of knowledge creation or dissemination. Publications, conferences, and patenting are examples of the intermediate outputs that program administrators may consider. Recent and ongoing SBIR evaluation studies are careful to include such measures in their calculation of program benefits (see NIH, 2003, and NRC, 2004). So, when valuable social benefits accrue before market introduction, program administrators will be supply funds to academic entrepreneurs for commercialization sooner than alternative private sources.

Even more importantly, both the structure and selection process of the SBIR program leads public investors to put less weight on technical and market uncertainties implying that these funds will be available sooner than alternative private sources. Phase 1 of the program is explicitly intended to finance a feasibility study to investigate the technical merit of the proposed concept - a proof of concept study. So, rather than interpreting technical uncertainty as a reason not to invest, the SBIR program is designed to accept higher levels of technical uncertainty. With respect to market uncertainty, the SBIR application for a Phase 1 study must identify and discuss the intended market opportunity for the innovation but no business plan or detailed market evaluation is required. This stands in stark contrast to more extensive market definition and research required by most private investors. Quite simply, the limited market due diligence required by SBIR implies that proposal evaluators place less weight on market uncertainties and will, therefore, invest earlier.

Toole and Turvey (2005) use a two-stage net present value (NPV) model to examine how initial public investment into an early-stage technology influences the financial returns for academic entrepreneurs and follow-on private investors. They identify three effects that combine to reduce the investment timing gap. First, public investment resolves some of the technical and market uncertainties. Second, for projects that remain feasible, public investment directly increases the NPV of the investment opportunity, a social return. In principle, this social return is a direct transfer from government to the academic entrepreneur. It acts as a financial incentive rewarding successful academic entrepreneurship while government bears the risk of failure. Third, to the extent that public and private investments are complementary, private follow-on investors increase their returns by leveraging their funding on the initial public 
investment. In the SBIR program, these investors also get the opportunity to leverage their money on the capabilities of the full-time academic entrepreneur.

Alternative forms of early-stage financing, when available, will typically have a higher cost to an academic entrepreneur in terms of both risk and return. Personal funds reduce savings and imply a higher personal risk than an SBIR subsidy. Banks loans require collateral, interest payments, and repayment. Venture capitalists and business angels require in depth market due diligence, although angels appear to be less demanding, and take an equity interest in the company, usually preferred stock. As a subsidy, SBIR funds do not require repayment or loss of ownership. SBIR allows academic entrepreneurs time to investigate the technical feasibility of their ideas and to prepare the market due diligence private investors require. Moreover, SBIR is the only financing source that offers a financial incentive to academic entrepreneurs. They capture the increased market value of the firm made possible by the public investment.

Hypothesis \#1: $\quad$ University researchers choose to commercialize through the SBIR program since SBIR funds are available earlier and cost less in terms of risk and return.

This real options view of investment into university-based technologies helps to clarify a mechanism by which participation in the SBIR program can "certify" firms for follow-on private investment as postulated by Lerner (1999). Venture capitalists and other private investors are unlikely to invest in a company because SBIR reviewers and administrators have approved a proposal and provided initial financial support. (For borderline cases, lowering the cost of commercialization through the subsidy might be enough to reduce the value of waiting.) For most cases, the increased probability of follow-on private investment comes from the SBIR firm's success at reducing technical and market uncertainties. It comes from the successful completion of Phase 1's proof of concept and Phase 2's product and market strategy development. So, except for borderline cases, there should not be any certification effect for companies that win only a Phase 1 SBIR award and fail to move past proof of concept.

This suggests two empirical tests of the certification hypothesis. A more stringent test would ask if follow-on venture capital funding is more likely for small firms that participate in the SBIR program and win a Phase 2 award relative to other similar non-participating firms. Unfortunately, we do not have data on non-SBIR participants to perform this test. Since we have 
SBIR participant firms, we can perform a less stringent test: Conditional on already being in the SBIR program, is follow-on venture capital funding more likely for those firms that win a Phase 2 award.

Hypothesis \#2: $\quad$ The probability of follow-on venture capital funding is greater for SBIR firms that complete the funded portion of the SBIR program indicated by winning a Phase 2 award.

\section{Discovery Scientist Involvement in Commercialization}

Consistent with the fact that most university-based technologies are very early-stage, there is broad agreement in the academic entrepreneurship and technology transfer literatures that some form of faculty involvement is critical. ${ }^{5}$ The most common forms of faculty involvement are consulting and sponsored research but recall that the SBIR program requires the PI to be employed full-time at the firm. This level of commitment is likely to benefit the firm in its pursuit of follow-on private financing. Asymmetric information between academic entrepreneurs and potential investors reduces the chances of obtaining funding. To maximize their returns, investors want to limit their risk of opportunistic behavior by entrepreneurs (Shane and Cable, 2002). In the presence of asymmetric information, a full-time commitment by the discovery scientist may signal credibility of the investment opportunity.

There is also evidence that full-time commitment by entrepreneurs improves the performance of the firm. Studying university spinoffs in the UK and Ireland, Blair and Hitchens (1998) found that full-time commitment by the entrepreneur was necessary to meet the numerous demands of running a new firm. In his interviews with founders, Shane (2004) finds that university spinoffs perform better when there is full-time commitment. He quotes an MIT academic entrepreneur as saying, "The major lesson I learned from founding this company is that you need to find a way to put your entire soul into it. It certainly reaffirmed the notion that if you don't do it full time, it goes slowly - that's exactly what happened." (Shane 2004, p. 249)

Zucker and coauthors have an important stream of research exploring the movement of university discoveries into private sector commercialization in biotechnology. They emphasize the movement of ideas in people based on the observation that intellectual human capital is often tacit knowledge held by the discovery scientist that is difficult to codify and communicate except through person-to-person interaction in the laboratory. To empirically measure the degree of 
tacit knowledge exchange through bench-level interaction, they use counts of articles coauthored between firm scientists and university scientists, some of whom have changed employment to firms. Their findings suggest that various measures of firm success including patenting and products in development significantly increase with the degree of involvement by discovery scientists.

Their work emphasizes the central role played by "star" scientists in the commercialization process. They define star scientists as those individuals with 40 or more genetic sequence discoveries as reported in the Genbank database prior to 1990. Zucker et al. (1998b) find that the location and timing of new firm formation is related to where and when these stars are publishing. Torero (2000) investigates the star researcher hypothesis in the semiconductor industry. Defining stars based on patent citation counts for the listed inventors, Torero finds that stars are positively and significantly related to the formation on new semiconductor firms.

Murray (2004), Shane and Stuart (2002), and Shane and Cable (2002) present evidence that the contribution of discovery scientists to commercial development extends beyond their intellectual human capital. Using interviews and quantitative data from 12 biotechnology firms, Murray (2004) suggests that discovery scientists also contribute their social capital to start-up firms. She highlights the importance of the scientist's "local laboratory" network, which includes their graduate students, as well as the scientist's "cosmopolitan" network, which captures their reputation and broader network of contacts. Shane and Stuart (2002) using data on MIT start-ups, find that social network ties to investors (angels or VC) decrease the probability of failure and increase the likelihood of venture capital funding. Based on survey data from venture capital and angel investors, Shane and Cable (2002) find that the probability of seedstage funding increases when entrepreneurs have a previous social tie to investors.

In our empirical work, we explore the hypothesis that full-time commitment by the academic entrepreneur is associated with better performance by SBIR firms measured in terms of follow-on venture capital investment, program completion (winning a Phase 2 award), and patenting. To do this we compare SBIR firms that employ a full-time academic entrepreneur, called scientist-linked firms, to those SBIR firm that do not have a full-time academic entrepreneur, called non-linked SBIR firms. Non-linked SBIR firms may have many contractual and informal relationships with university researchers that we do not observe. To the extent that 
these relationships make the non-linked SBIR firms similar to our scientist-linked firms, it reduces our chances of observing statistically significant differences. In this sense, our test of the importance of full-time commitment should be a fairly strong. However, our data are not rich enough to decompose the contribution of academic entrepreneurs into their intellectual human capital, social capital, or signaling components. Our empirical results will capture all three effects on scientist-linked SBIR firms.

Hypothesis \#3: $\quad$ Scientist-linked SBIR firms perform better than non-linked SBIR firms in terms of follow-on venture capital investment, program completion, and patenting.

We also explore whether SBIR biomedical academic entrepreneurs are star scientists using cumulative NIH research awards as our indicator of academic achievement. Cumulative NIH grants should be positively related to academic publications. In fact, Leibert (1977) finds that past research publications are strongly related to successful grant getting. Following the spirit of Zucker et al. (2002), we ask if SBIR commercialization is "all in the stars." That is, do star biomedical scientists drive the commercialization process using the SBIR channel? In addition, we examine if NIH stars are associated with greater chances for follow-on venture capital investment, SBIR program completion (winning a Phase 2 award), and firm patenting.

Hypothesis \#4: $\quad$ The typical SBIR biomedical academic entrepreneur is an NIH star scientist.

Hypothesis \#5: $\quad$ Star scientist-linked SBIR firms perform better than non-star scientist linked firms and non-linked SBIR firms in terms of follow-on venture capital investment, program completion, and patenting.

\section{Data and Methodology}

\section{Data Sources}

Our empirical work draws on five sources of data. First, we use the NIH Computer Retrieval of Information on Scientific Projects (CRISP) database to identify the population of 
biomedical researchers that received at least one research award between 1972 and 1996. After 1996, the NIH stopped publicly reporting the award amounts for individual grants and contracts. For each award, the database includes the grant number, research activity code, grant title and abstract, the PI name, the NIH awarding institution, the fiscal year, the award amount, the institutional affiliation of the PI at the time of award, the institution's street address, city, state, and an NIH award type code. These data include all Dept. of Health and Human Services (DHHS) SBIR awards.

The second source of data is the Small Business Administration's SBIR public use database. SBA is the coordinating agency for the SBIR program and their public data are available since 1983. These data provide the firm name, street address, city, state, SBIR phase, year of award, awarding agency, award amount, topic, and indicators for minority or woman owned. Because the SBA data do not include the PI name, we supplemented these data with the PI names from four of the largest SBIR agencies . These are: Dept. of Defense, NASA, NSF, and DHHS.

The NIH and supplemented SBA data are enough to identify SBIR academic entrepreneurs and compare them along some dimensions to other non-SBIR biomedical researchers but we require additional information on each firm's venture funding and patenting activity to test our hypotheses. We use Securities Data Corporation's (SDC) VentureXpert database (1977-1998) to identify which SBIR firms received venture capital and the date of their first round. For patenting activity, we use the NBER patent database to identify all patents assigned to SBIR participant firms (Hall et al., 2001).

\section{Academic Entrepreneurs and Stars}

To identify SBIR biomedical academic entrepreneurs we match individual PIs by name between the NIH researcher database the supplemented SBA SBIR database. Name matching is a difficult process but can be done fairly accurately if there is enough cross-referencing information. The first step was to standardize the format and insure the consistency of the names within each separate database. This was done manually for each. The NIH database required a review over 610,000 individual records. There were various errors in spelling, married names, hyphens, spacing, etc. As mentioned, the other data items in each record were used to cross- 
reference and identify errors. In the end, we had 79,967 unique NIH PIs and 24,287 unique SBIR PIs. For SBIR at DHHS, there were 4,196 unique PIs between 1983 and 1996.

Matching names across the two PI databases proved quite difficult. The central problem was the lack of cross referencing information common to both files. Because very common names like "Thomas Jones" and "John Smith" created numerous false matches, we had to "blacklist" these names to avoid introducing significant errors. During the matching process it also became clear that all matched PIs won at least one SBIR award from the DHHS. While somewhat surprising, this is consistent with the differences between agencies in their technology foci. This fact turned out to be very helpful in the matching process. By using the NIH database to form our final group of biomedical academic entrepreneurs, we avoided the inconsistencies introduced by matching across databases.

Our name matching produced 693 potential academic entrepreneurs. However, we eliminated those NIH researchers that received their pre-SBIR research award while associated with a firm or policy oriented institution. Almost all were firm associated matches and this reduced our potential academic entrepreneur group to 514 people. Next, there were a number of individuals whose last NIH research grant was more than four years prior to their first SBIR award. Because we are unsure if they changed jobs during this interval, we eliminated those people and reduced our potential matches to 387. Finally, there were a number of people that won an SBIR award first and then moved to academic institutions to do research. These people might be graduate students who tried to commercialize but we are not sure so we eliminated those individuals. Our final group of academic entrepreneurs came to 337 people. We manually checked these people to verify that they were, in fact, biomedical researchers before they won their first SBIR award. It should also be noted that a fair number of these people won NIH research awards subsequent to their SBIR participation. This could indicate either of two possibilities. First, their proof of concept failed and they returned to academic research or their SBIR experience was successful but they delegated further development to others, perhaps retaining a consulting and equity position in the firm. The final group of academic entrepreneurs makes up about 8\% of all the unique PIs that won an SBIR award from DHHS between 1983 and 1996.

As discussed in Section II, Zucker and coauthors have emphasize the central role of star scientists in the commercialization process of university-based technologies, specifically in 
biotechnology. While there is no single measure of "starness," the measures in the literature use absolute "productivity" to define stars. Underlying these measures, of course, is some time dimension so that most stars are likely to be older researchers. Following suit, we use a biomedical researcher's cumulative value of NIH research awards to define stars. Some studies use total publications or the number of radical discoveries as the starness indicator. Although this would certainly be interesting to investigate, we argue that accumulated research grants are an appropriate measure of starness for this population of researchers. For those researchers running laboratories using NIH funds, cumulative grants will also capture their skill at organizing a research team, which is a skill that has value in the commercialization process as well.

Using cumulative NIH awards over the 1972 to 1996 period, we define an NIH star as a biomedical researcher in the top decile of this distribution. In the regression analysis, these individuals are coded as stars using a dummy variable. The SBIR firms associated with these stars are also identified. To test if the typical academic entrepreneur is a star scientist, hypothesis \#4 in Section II, we use a cross-sectional Probit model explaining the probability of being an $\mathrm{NIH}$ star as a function of being an SBIR academic entrepreneur, the researcher's years in the NIH system, their organizational affiliation and their field of research.

(1) $\operatorname{Pr}(\text { NIHstar }=1 \mid \mathbf{X})_{\mathrm{i}}=\Phi\left(\beta_{0}+\beta_{1} A E_{i}+\beta_{2}\right.$ ResYears $_{i}+\beta_{3}$ Org $_{i}+\beta_{4}$ Field $\left._{i}\right)$

where NIHstar is a dummy variable indicating that the researcher is an NIH star; $A E$ is a dummy variable indicating if the scientist is an SBIR academic entrepreneur; ResYears is a count of total years the researcher is active in the NIH system starting from year of first research award to 1996; Org is the type of research institution affiliated with the NIH researcher, either university or non-profit research organization; and Field broadly captures differences across biomedical research areas (cancer, central nervous system, cardiovascular, etc.) as indicated by the awarding component of the NIH.

\section{$\underline{\text { SBIR Firm Database }}$}

We construct a panel database of SBIR program participants between 1983 and 1996 to investigate the hypotheses related to SBIR firm performance. The panel only includes firms that won an SBIR award from DHHS. We use only firms from DHHS because these firms share a similar health/medical technology focus, which is a partial control for differences in 
technological opportunities. The dataset has 2,855 unique firms that participated in the program over this period. Our biomedical academic entrepreneurs are associated with 240 firms (some of the 337 individuals identified previously could not be matched to the firm level data due to inconsistencies between the firm names in the NIH PI records and the firm names recorded in the SBA database). Also, there were some cases where two or more academic entrepreneurs were associated with the same firm but joined at different times. For these cases we use the year in which the first academic entrepreneur joined the firm.

Table 1 summarizes the variables in our database and Table 2 provides descriptive statistics for the firm-year observations separately by scientist-linked SBIR firms and non-linked SBIR firms. For all three measures of patenting, the firm-year statistics show that scientistlinked SBIR firms patent more, on average. Receiving first-round venture capital funding after first SBIR award is also higher for these firms. The other variables, SBIR program information and regional controls, are quite similar between the scientist-linked and non-linked firms.

\section{Firm Regression Models and Methods}

The results section presents three sets of regressions testing the hypotheses about firm performance. The first set of regressions examines the factors influencing the probability of follow-on private investment by venture capitalists. We expect follow-on $\mathrm{VC}$ investment to increase in response to three factors: (1) the employment of an academic entrepreneur (hypothesis \#3); (2) the star status of the academic entrepreneur (hypothesis \#5); and (3) the completion of the funded portion of the SBIR program (hypothesis \#2). We estimate a Probit model:

(2) $\operatorname{Pr}(\text { VCafter }=1 \mid \mathbf{X})_{\mathrm{it}}=\Phi\left(\beta_{0}+\beta_{1} A E_{i t}+\beta_{2}\right.$ Star $_{i t}+\beta_{3} P 2_{i t-1}+\beta_{4} S B I R \$_{i t-1}+\beta_{5}$ PatentStk $_{i-1}+\beta_{6} M A_{i}$ $+\beta_{7} C A_{i}+\beta_{8}$ Timedum $)$

where the dependent variable VCafter is a dummy indicating whether the SBIR firm received its first round of venture capital funding after its first SBIR award; $A E$ is a dummy variable indicating if the firm is linked to a biomedical academic entrepreneur in year $t$; Star is a dummy variable indicating if the academic entrepreneur is also a NIH star scientist; $P 2$ is a dummy variable indicating the firm won a Phase 2 award in year prior to receiving VC investment. 
Follow-on venture capital investment is also going to be influenced by how venture capitalists perceive the distribution of technological opportunities across firms and time. Venture capitalists will focus their investments in innovatively "hot" firms within promising technological areas. We measure a firm's "innovativeness" by using firm-year patent stocks. Patent stocks should be a good measure in sectors that rely heavily on patenting for competitive advantage. For this reason, we focus on firms active in the health/medical technological area where patenting is important. This technological area is defined by the population of SBIR awardees from DHHS. The variable, PatentStk $k_{i t-1}$, measures the firm's stock of patents cumulated by year of application.

Investment opportunities for VCs will also change across firms and time to the extent that follow-on private investment can be leveraged on initial public investment. Holding the innovativeness of a firm constant, we suppose that firms with greater initial public investment allow venture capitalists to "piggyback" their investment more effectively. That is, firms that win more SBIR funds are more attractive prospects for VC investors. To control for this incentive, we include the real value of SBIR awards received by the firm in the year prior to VC investment, $S B I R \$_{t-1}$.

We also control for geographic concentration and overall trends in investment opportunities. Because venture capital investment is heavily concentrated in Massachusetts and California we include dummy variables for these regions. Yearly time dummies capture exogenous trends in venture capital investment that are common across firms in our health/medical sector.

Our second set of regressions look at the probability of completing the SBIR program. Without information on commercialization outcomes, we use the receipt of a Phase 2 award as the indicator program completion. Phase 2 is the last funded stage of the program. We expect the chances of making it through the technical feasibility stage (Phase 1) and successfully winning Phase 2 award are increased by the employment of an academic entrepreneur (hypothesis \#3) and the star status of the scientist (hypothesis \#5). We estimate a Probit model:

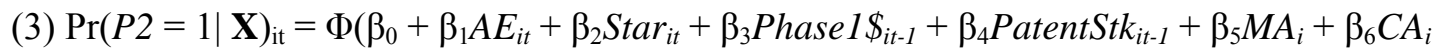

$$
+\beta_{7} \text { Timedum) }
$$


where Phase $1 \$$ is the real value of Phase 1 awards in the preceding year and all other variable are defined as before.

Our third group of regressions look at the SBIR firm's patenting behavior. We expect SBIR firms that employ an academic entrepreneur have a greater chance of patenting and to patent more (hypothesis \#3). Based on the work of Zucker and coauthors, the star status of the academic entrepreneur should also increase the probability that the firm patents as well as the number of patents (hypothesis \#5). We use the following specifications to test these hypotheses:

(4) $\operatorname{Pr}(D P A T=1 \mid \mathbf{X})_{\mathrm{it}}=\Phi\left(\beta_{0}+\beta_{1} A E_{i t}+\beta_{2}\right.$ Star $_{i t}+\beta_{3} P 2_{i t-1}+\beta_{4} S B I R \$_{i t-1}+\beta_{5}$ PatentStk $\left._{i t-1}+\beta_{6} M A_{i}+\beta_{7} C A_{i}\right)$

(5) $\mathrm{E}\left[\right.$ Patents $\left._{i t} \mid \mathbf{X}_{\mathbf{i t}}\right]=\exp \left(\beta_{0}+\beta_{1} A E_{i t}+\beta_{2}\right.$ Star $_{i t}+\beta_{3} P 2_{i t-1}+\beta_{4} S B I R \$_{i t-1}+\beta_{5}$ PatentStk $\left._{i t-1}+\beta_{6} M A_{i}+\beta_{8} C A_{i}\right)$

where DPAT is a dummy variable that firm i applied for at least one patent in period $\mathrm{t}$, and Patents represents the counts of patent applications. All other variables are defined as above.

Even after the extensive data collection and matching performed for this research, our data are not rich enough to rule out the possibility that academic entrepreneurs join higher quality firms. This possibility suggests that the employment of an academic entrepreneur may be endogenous because of unobserved firm quality. We use the NBER patent data to partially address this concern; however, an instrumental variables approach similar to the one used by Kortum and Lerner (2000) would be better.

\section{Empirical Findings}

$\underline{\text { SBIR Academic Entrepreneurship }}$

Section II argues that the SBIR program is an attractive commercialization channel for university researchers because SBIR funds are available earlier than many private sources of finance and initial public investment costs the entrepreneur less in terms of risk and return (hypothesis \#1). Our matching procedure found 337 biomedical academic researchers that chose to commercialize through the SBIR program over the fourteen year period, 1983 to 1996. Nationally, this is an average of 24 people per year. However, these entrepreneurs have not entered the program uniformly over time. As seen in Figure 1, following a jump in 1985, SBIR biomedical academic entrepreneurship declined until 1991 but has shown steady growth thereafter. This growth period, 1991-1996, is also a time when venture capital investments were 
growing. Lerner (2000) notes that the growth in venture capital might diminish the role of the SBIR program in funding small firms; however, the program appears to be attracting more biomedical academic entrepreneurs in spite of greater venture capital investment.

Biomedical academic entrepreneurship, however, is a small part of the overall SBIR program at DHHS. Figure 2 and Figure 3 show the share of Phase 1 and Phase 2 awards going to academic entrepreneurs, respectively. Their share of Phase 1 awards is quite small and remains roughly constant over time even as the DHHS SBIR budget has grown significantly. Academic entrepreneurs do slightly better with Phase 2 awards. Since the late 1980s, their share of Phase 2 awards has been greater than their share of Phase 1 awards. This suggests that scientist-linked firms have been more successful at progressing through the DHHS program.

What about the SBIR biomedical academic entrepreneurs themselves? Are they different from their non-SBIR peers? To get a descriptive first cut at this issue with our data, we compare the grantsmanship of SBIR academic entrepreneurs to non-SBIR NIH researchers. Grantsmanship is measured by cumulative NIH awards (nominal dollars are deflated using BRDPI index for biomedical research developed by the BEA). Figure 4 looks at where these researchers perform their work. The most notable difference occurs in the not-for-profit research institutions category. It suggests that relatively more SBIR academic entrepreneurs are associated with this type of institution prior to commercialization than is typical of other NIH researchers. Otherwise, the two groups are broadly similar in both number and value of awards.

Recall that NIH stars are defined as those individuals in the top decile of cumulative research awards. Using this cut-off, we find that $14 \%$ of the SBIR academic entrepreneurs are NIH stars. However, we also ask if the average SBIR biomedical academic entrepreneur is a star. This is important because it indicates who is taking advantage of the SBIR program for commercialization. The results are presented in Table 3. Column A reaffirms the "absolute" star definition and shows that SBIR academic entrepreneurs are more likely to be stars. As we add in our controls, being an academic entrepreneur is no longer significantly associated with being a star. These results show that, on average, an SBIR academic entrepreneur is not a star scientist. ${ }^{6}$

\section{Scientist full-time Involvement on Performance}

Table 4 presents our Probit estimates of Equation (2) looking at the probability of receiving follow-on venture capital investment. The table reports the estimated coefficients and their standard errors. Among the 240 scientist-linked SBIR firms, 6.3\% received venture capital 
after their first SBIR award. The percentage receiving venture capital after SBIR increases to $8.6 \%$ (marginal effect at sample mean is not presented in table) among those firms whose academic entrepreneur is also an NIH star.

Column A in Table 4 shows that scientist-linked SBIR firms have a higher probability of receiving follow-on VC than non-linked firms. Calculating the marginal impact, the probability getting VC increases by $2.2 \%$ if a non-linked firm becomes a scientist-linked SBIR firm. This almost triples the firm's expected probability of follow-on financing. The NIH star status of the academic entrepreneur further increases the chances for follow-on venture capital investment by an additional 1.1\%. These findings support hypotheses \#3 and \#5 that full-time commitment by the discovery scientist is valuable; however, we cannot distinguish the exact mechanism through which this value is transmitted.

Column B adds the other SBIR variables. Wining a Phase 2 award increases the probability of follow-on VC. At the margin, winning a Phase 2 award doubles the firm's expected chances. This is consistent with the idea that SBIR participation certifies firms by allowing them sufficient time to reduce technical and market uncertainties as described in hypothesis \#2. The leveraging incentive for follow-on venture capital investment is also positive and significant. Increasing initial public investment in the firm increases the chances for followon VC investment. Our other control variables are significant and have the expected sign. Firm's with larger patent stocks or firms located in either California or Massachusetts have a higher probability of receiving venture investment after SBIR.

Table 5 presents our results on the probability of completing the SBIR program as indicated by the chance of winning a Phase 2 award. The first year of the program is dropped since no firms won a Phase 2 award in 1983. Focusing on the results in column B, which include the dollar value of Phase 1 awards, we find that firms with an academic entrepreneur are $1.8 \%$ more likely to finish the program (marginal impact not shown in table). Having an academic entrepreneur employed full-time at the firm increases the average probability of winning a Phase 2 award by $30 \%$. Star scientists, however, make no additional contribution above and beyond their entrepreneurial peers. This suggests that having an academic entrepreneur working on the technical feasibility part of the commercialization process is quite valuable, at least within the SBIR program at DHHS. The signs and statistical significance of our other control variables are as expected. Interestingly, once Phase 1 awards are held constant, the regional advantage of 
being located in California is no longer significant. It is difficult to know exactly why this is true but it does suggest that California firms are better at winning only Phase 1 awards.

Table 6 shows at the effect of academic entrepreneurs on firm patenting performance. Column A reports the Probit results for the probability of any patenting activity. Consistent with our other findings, full-time scientist-linked SBIR firms have a greater probability of patenting relative to their non-linked counterparts. Contrary to Zucker et al. (2002), we do not find that star scientists increase the chance of patenting beyond their status as an academic entrepreneur. Column B reports our findings using a Negative Binomial model for the number of firm patents. While the overall results are broadly consistent with the Probit model, the impact of NIH stars and winning a Phase 2 award are different. The results indicate that having an NIH star significantly reduces the number of firm patents. In principle, star scientists have the busiest schedules with multiple demands on their time. While this result is unexpected, star scientists might be less committed than a typical scientist to the firm given their level of achievement and the demands on their time. Insignificance of the Phase 2 dummy is less troubling since the technical feasibility studies in Phase 1 are expected to produce the inventions that warrant patents. Phase 2 is a product development phase. Overall, we see these results as further evidence supporting the idea that university scientist involvement is important for commercialization.

\section{Conclusions}

This paper has explored the role of the SBIR program as an entrepreneurship policy, looking specifically at biomedical researchers that chose to pursue commercialization through this program. Even though entrepreneurship was not an explicit legislative aim of the program, we believe the SBIR program does have a useful role to play in funding early-stage universitybased technology firms by increasing the availability of financial capital and allowing entrepreneurs time to reduce technical and market uncertainties surrounding their ideas.

Our empirical work indicates that biomedical academic entrepreneurship through the program is small in terms of the number and dollar value of awards but, since 1991, the number of research scientists using SBIR as a commercialization channel is on the rise. While the typical SBIR biomedical academic entrepreneur is not a star scientist, scientist-linked SBIR firms have a higher probability of follow-on venture capital investment, program completion and 
better innovative performance as measured by patents. Interestingly, the NIH stars within this group of entrepreneurs only increase the chances of follow-on venture capital investment and do not increase the probability of winning a Phase 2 award or patenting. Finally, we find evidence consistent with Lerner's (1999) certification hypothesis. That is, firms that complete the SBIR program are more likely to receive follow-on venture capital funding.

It is important to keep in mind that our empirical work is based on a limited set of firm level control variables. We see our results as suggestive but not definitive. Data limitations required us to work at a fairy high level of generality and prevented us from addressing the potential endogeneity between a firms' ex ante quality and the university scientist's choice to join that firm. Further, one cannot tell from our work exactly how the academic entrepreneur is transferring her human and social capital to the firm nor can we tell the relative importance of these types of capital. Nevertheless, this research does lay the groundwork for future research to probe deeper into these issues. 


\section{Notes}

1. There are currently eleven federal agencies participating in the SBIR program. These are: Department of Defense, Department of Commerce, Department of Agriculture, Department of Education, Department of Health and Human Services, Department of Energy, Department of Transportation, Department of Homeland Security, Environmental Protection Agency, National Science Foundation, and National Aeronautics and Space Administration.

2. Lerner (1999) also considers the SBIR program as an entrepreneurship policy, calling it "public venture capital," however, his analysis focuses on evaluating the effects of the program on participant firms relative to non-participant firms. Other studies that focus on evaluating various aspects of the SBIR program include: Archibald et al. (2003), Audretsch (2003), Audretsch et al. (2002), NIH (2003), and Wallsten (2000).

3. See, for instance, Branscomb and Auerswald (2001), Colyvas et al. (2002), Lowe (2001), Shane (2004), Thursby et al. (2002) and the references therein.

4. Branscomb and Auerswald (2001) include a "financial gap" in their discussion of the challenges to crossing the "Valley of Death" between invention and innovation. Chapter 1 is particularly relevant.

5. See, for instance, Lowe (2001), Shane (2004), Thursby et al. (2001, 2003) and the references therein.

6. We also performed a non-parametric matching procedure in which each academic entrepreneur is matched with an appropriate "twin" conditional on researcher years and NIH research field. We tested various matching routines, e.g. drawing only one twin randomly from the control group of non-entrepreneurial scientists versus drawing, say, four controls for each observation. The matching always confirmed the Probit model results that SBIR academic entrepreneurs are not typically star scientists. 


\section{REFERENCES}

Archibald, Robert B., and David H. Finifter. (2003). "Evaluating the NASA small business innovation research program: preliminary evidence of a trade-off between commercialization and basic research," Research Policy, Vol. 32, pp. 605-619.

Audretsch, David B. (2003). "Standing on the Shoulders of Midgets: The U.S. Small Business Innovation Research Program (SBIR)," Small Business Economics, Vol. 20, pp. 129-135.

Audretsch, David B., Albert N. Link and John T. Scott. (2002). "Public/private technology partnerships: evaluating SBIR-supported research," Research Policy, Vol. 31, pp. 145158.

Audretsch, David B., Juergen Weigand and Claudia Weigand. (2002). "The Impact of the SBIR on Creating Entrepreneurial Behavior," Economic Development Quarterly, Vol. 16, No. 1, February 2002, pp. 32-38.

Bhide, Amar V. (2000). The Origin and Evolution of New Business, New York, NY: Oxford University Press.

Blair, Desmond M., and David M W N Hitchens. (1998). Campus Companies - UK and Ireland, Aldershot, England: Ashgate Publishing Ltd.

Branscomb, Lewis M. and Philip E. Auerswald. (2001). Taking Technical Risks: How Innovators, Managers, and Investors Manage Risk in high-Tech Innovations, Cambridge, MA: MIT Press.

Brown, George E Jr., and James Turner. (1999). "Reworking the Federal Role in Small Business Research, Issues in Science and Technology, Summer 1999, pp. 51-58.

Cockburn, Iain M., and Rebecca Henderson. (1997). "Public-private Interaction and the Productivity of Pharmaceutical Research," NBER Working Paper No. 6018, Cambridge, MA, April 1997.

Colyvas, Jeannette, Michael Crow, Annetine Gelijns, Roberto Mazzoleni, Richard R. Nelson, Nathan Rosenberg, and Bhaven N. Sampat. (2002). "How do university inventions get into practice?” Management Science, Vol. 48, No. 1, January 2002, pp. 61-72.

Di Gregorio, Dante and Scott Shane. (2003). "Why do some universities generate more startups than others?" Research Policy, Vol. 32, pp. 209-227.

Dixit, Avinash. (1992). "Investment and Hysteresis," Journal of Economic Perspectives, Vol. 6, No. 1, Winter 1992, pp. 107-132. 
Gans, Joshua S. and Scott Stern. (2000). "When Does Funding Research by Smaller Firms Bear Fruit?: Evidence from the SBIR Program, Economics of Innovation and New Technology, Vol. 12, pp.361-84.

Gompers, Paul, Josh Lerner, and David Scharfstein. (2003). "Entrepreneurial Spawning: Public Corporations and the Genesis of New Ventures, 1986-1999," NBER Working Paper No. 9816, Cambridge, MA, July 2003.

Hall, Bronwyn H., Adam B. Jaffe, and Manuel Trajtenberg. (2001). "The NBER Patent Citations Data File: Lessons, Insights and Methodological Tools," NBER Working Paper No. 8498, Cambridge, MA.

Kortum, Samuel S. and Joshua Lerner. (2000). "Assessing the Contribution of Venture Capital to Innovation," RAND Journal of Economics, 31(4), 2000, 674-692.

Leibert, Roland J. (1977). "Research-Grant Getting and Productivity among Scholars," Journal of Higher Education, Vol. 48, pp. 164-192.

Lerner, Josh. (1999). "The Government as Venture Capitalist: The Long-run Impact of the SBIR program," Journal of Business, vol.72, no. 3, pp. 285-318.

Lerner, Josh. (2000). “The Problematic Venture Capitalist,” Science, Vol. 287, No. 5444, pp. 977-979.

Louis, Karen S., David Blumenthal, Michael E. Gluck, and Michael A. Stoto. (1989). "Entrepreneurs in Academe: An Exploration of Behaviors among Life Scientists," Administrative Science Quarterly, Vol. 34, pp. 110-131.

Louis, Karen S., Lisa M. Jones, Melissa S. Anderson, David Blumenthal, and Eric G. Campbell. (2001). "Entrepreneurial, Secrecy, and Productivity: A comparison of Clinical and NonClinical Life Sciences Faculty,” Journal of Technology Transfer, Vol. 26, pp. 233-245.

Lowe, Robert A. (2001). "The Role and Experience of Start-ups in commercializing Inventions: Start-up Licensees at the University of California, in Entrepreneurial Inputs and Outcomes: New Studies of Entrepreneurship in the United States, Gary D. Libecap, ed. New York, NY: Elsevier Science.

Murray, Fiona. (2004). "The role of academic inventors in entrepreneurial firms: sharing the laboratory life," Research Policy, Vol. 33, pp. 643-659.

National Institutes of Health, Office of Extramural Research. (2003). National Survey to Evaluate the NIH SBIR Program, Dept. of Health and Human Services, July 2003.

National Research Council. (1999). The Small Business Innovation Research Program: Challenges and Opportunities. Charles W. Wessner, ed. Washington, D.C.: National Academy Press. 
National Research Council. (2004). An Assessment of the Small Business Research Program: Project Methodology. Committee on Capitalizing on Science, Technology, and Innovation. Washington, D.C.: National Academy Press.

Pindyck, Robert S. (1991). "Irreversibility, Uncertainty, and Investment," Journal of Economic Literature, Vol. 29, No. 3, September 1991, pp. 1110-1148.

Shane, Scott. (2004). Academic Entrepreneurship: University Spinoffs and Wealth Creation. New Horizons in Entrepreneurship, Sankaran Venkataraman, ed. Northampton, MA: Edward Elgar Publishing.

Shane, Scott and Daniel Cable. (2002). "Network Ties, Reputation, and the Financing of New Ventures," Management Science, Vol. 48, No. 3, March 2002, pp. 364-381.

Shane, Scott and Toby Stuart. (2002). "Organizational Endowments and the Performance of University Start-ups,” Management Science, Vol. 48, No. 1, January 2002, pp. 154-170.

Torero, Maximo. (2000). "Analyzing the Spillover Mechanism on the Semiconductor Industry in the Silicon Valley and Route 128," Econometric Society World Congress 2000 Contributed Paper 0090, Econometric Society, available at http://ideas.repec.org/pto34.html

Thursby, Jerry G., R. Jensen, and Marie C. Thursby. (2001). "Objectives, Characteristics and Outocmes of University Licensing: A Survey of Major U.S. Universities," Journal of Technology Transfer, Vol. 26, pp. 59-72.

Thursby, Jerry G., and Marie C. Thursby. (2002). "Who Is Selling the Ivory Tower? Sources of Growth in University Licensing," Management Science, Vol. 48, No. 1, January 2002, pp. 90-104.

Thursby, Jerry G., and Marie C. Thursby. (2003). "Are Faculty Critical? Their Role in University-Industry Licensing,” NBER Working No. 9991, Cambridge, MA, September 2003.

Toole, Andrew A. and Calum Turvey. (2005). "The Relationship between Public and Private Investment in Early-stage Technology Firms: Is there a Certification Effect?," prepared for the $9^{\text {th }}$ ICABR International Conference. Ravello, Italy, May 2005.

Wallsten, Scott. (2000). "The effects of government-industry R\&D programs on private R\&D: the case of the Small Business Innovation Research Program," Rand Journal of Economics, Vol. 31, No. 1, Spring 2000, pp. 82-100.

Zucker, Lynne G., Michael R. Darby, and Jeff S. Armstrong. (1998a). "Geographically Localized Knowledge: Spillovers and Markets," Economic Inquiry, Vol. 36, No. 1, January 1998, pp. 65-86. 
Zucker, Lynne G., Michael R. Darby, and Marilynn B. Brewer. (1998b). "Intellectual Human Capital and the Birth of U.S. Biotechnology Enterprises," American Economic Review, Vol. 88, No. 1, March 1998, pp. 290-306.

Zucker, Lynne G., Michael R. Darby, and Jeff S. Armstrong. (2002). "Commercialization Knowledge: Capture, and Firm Performance in Biotechnology," Management Science, Vol. 48, No. 1, January 2002, pp. 138-153. 


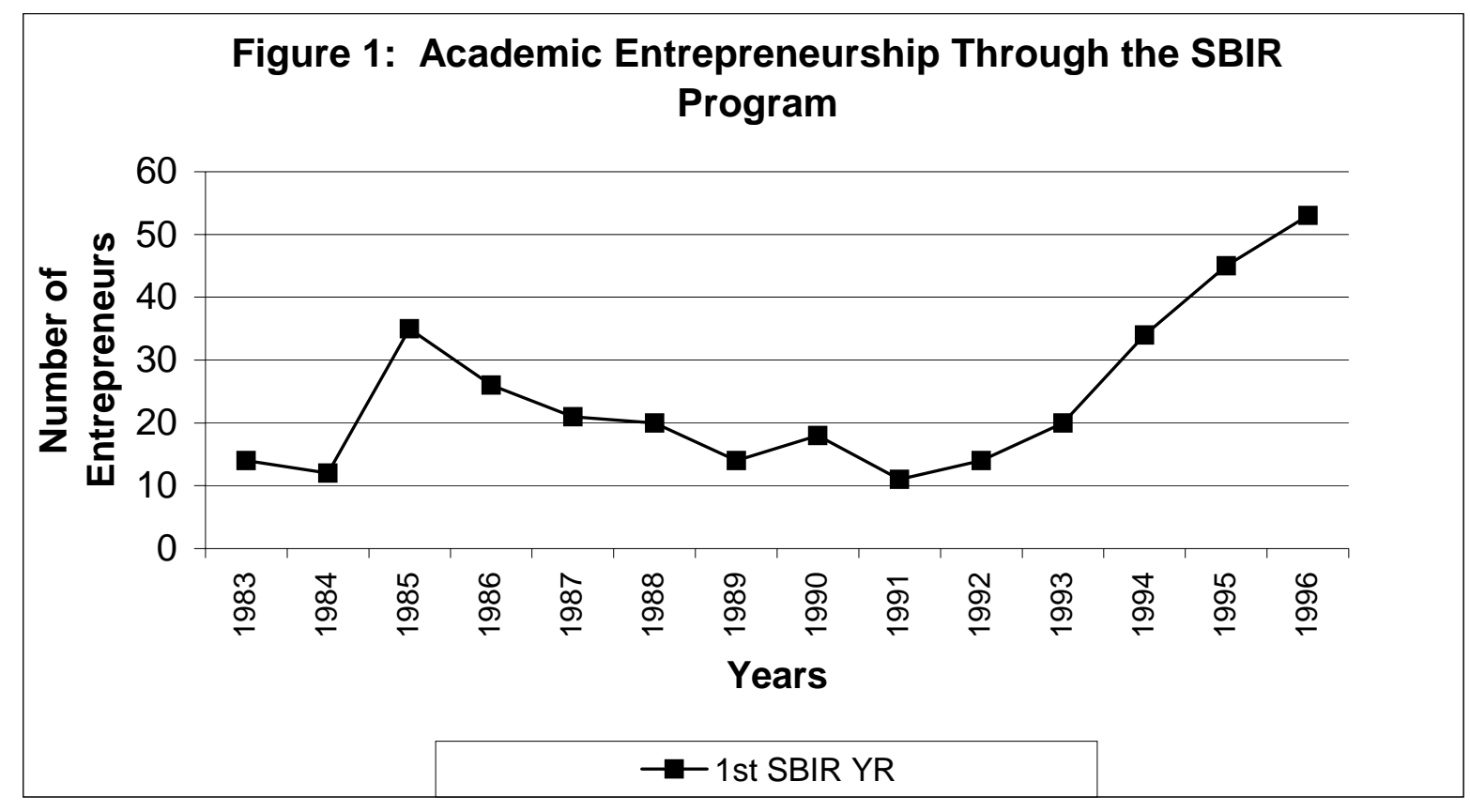

Figure 2: NIH SBIR Phase 1 Awards

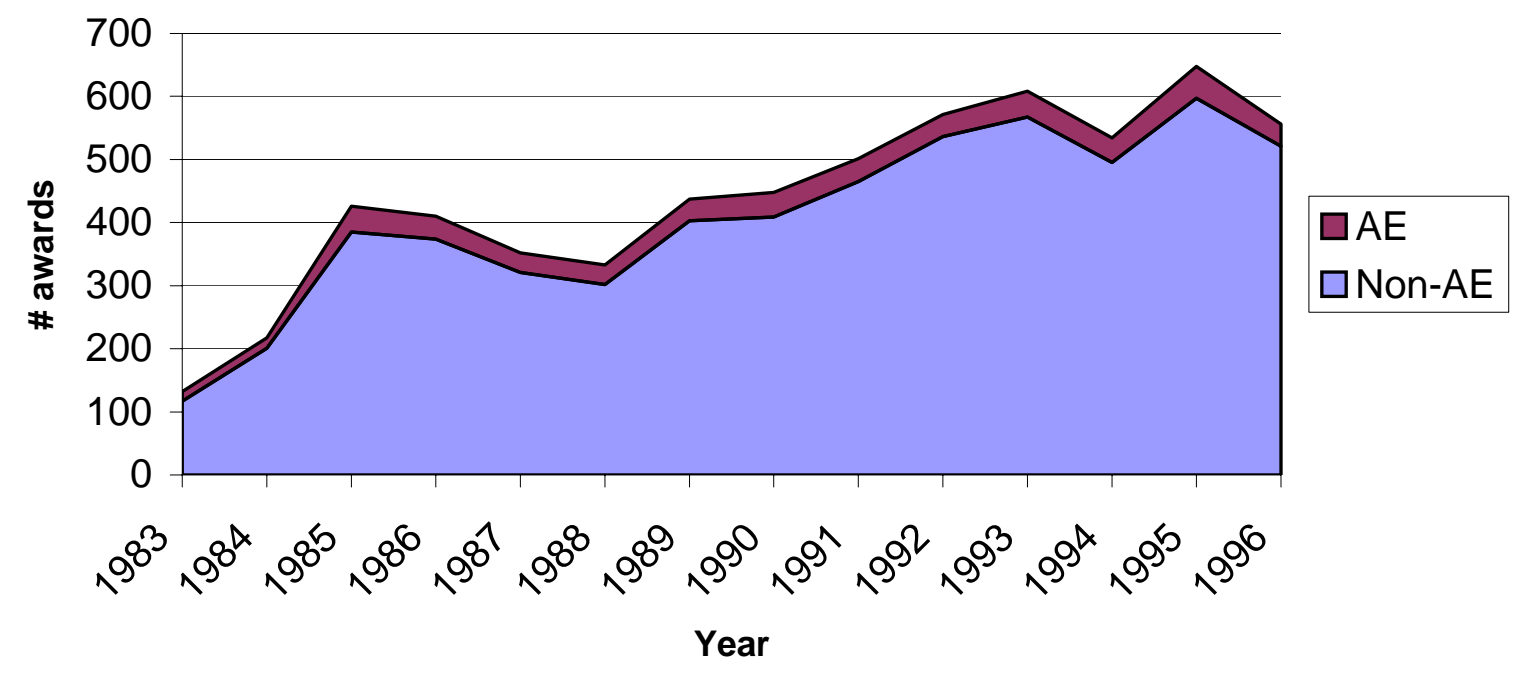



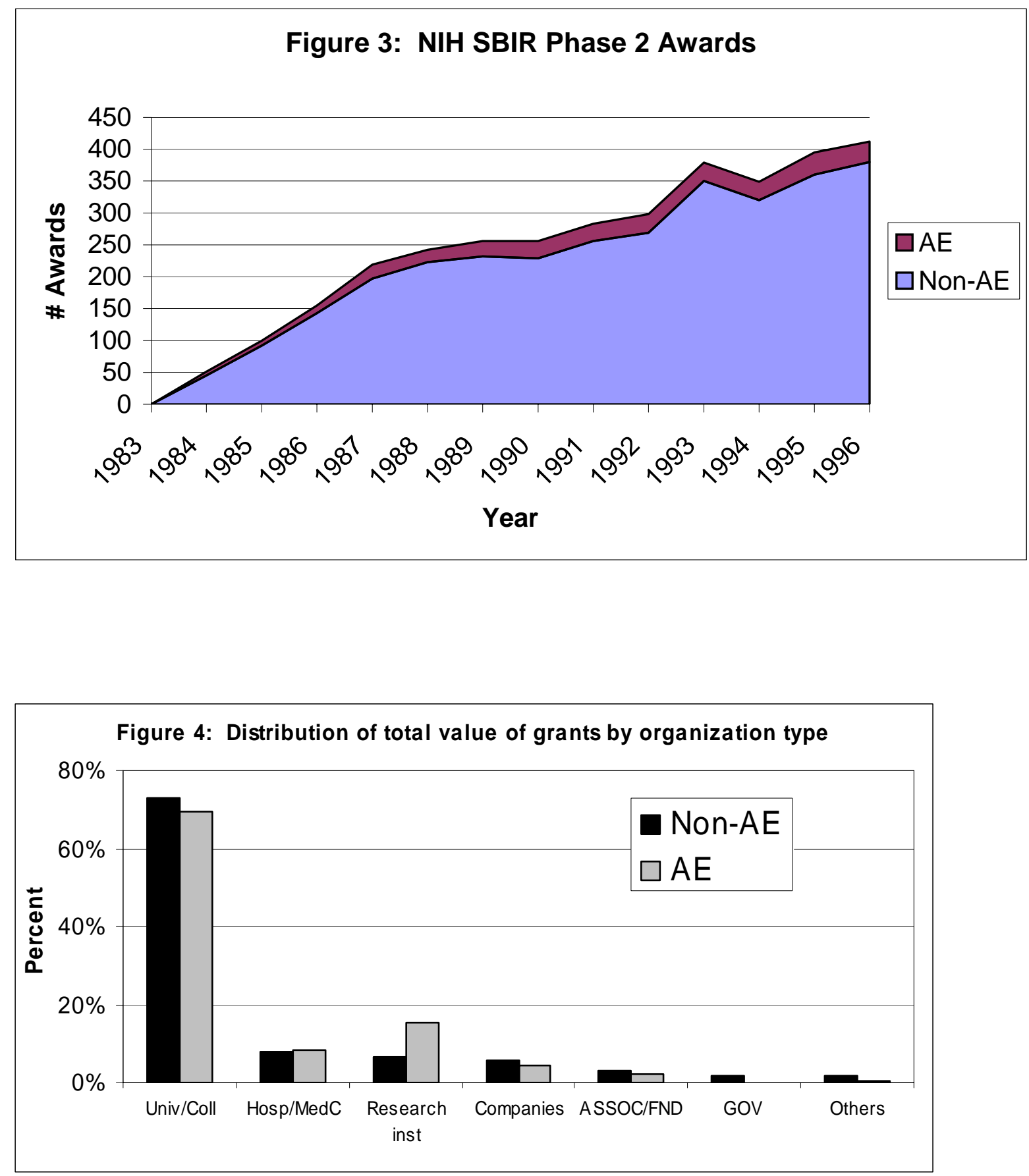
Table 1: Variable Definitions and Measurement

\begin{tabular}{|c|c|}
\hline Patents $_{\text {it }}$ & Number of patent applications of firm $\mathrm{i}$ in year $\mathrm{t}$ \\
\hline$D P A T_{\text {i t }}$ & $\begin{array}{l}\text { Dummy indicating that firm i filed at least one patent in period } t \\
{\left[\mathrm{D}\left(\text { Patents }_{\mathrm{it}}>0\right)\right]}\end{array}$ \\
\hline PatentStk $_{\mathrm{i}, \mathrm{t}-1}$ & $\begin{array}{l}\text { Patent stock of firm i in period } t-1 \text {; } \\
\text { calculated as PSTOCK } \mathrm{it}=(1-\mathrm{d}) * \text { PSTOCK }_{\mathrm{it}}+\mathrm{PATENT}_{\mathrm{i}} \text {, } \\
\text { where } \mathrm{d} \text { is set to } 15 \% \text { as common in the literature }(\text { see e.g. Griliches/Mairesse } \\
1984) \text {. The initial value of PSTOCK is equal to zero in } 1975 \text {. Due to the } \\
\text { included depreciation rate of knowledge }(\mathrm{d}=15 \%) \text {, the bias arising from the } \\
\text { initial condition, PSTOCK i, } 1975=0 \text {, should be negligible in our sampled } \\
\text { time period starting in } 1983 \text {. }\end{array}$ \\
\hline$A E_{\mathrm{it}}$ & $\begin{array}{l}\text { The academic entrepreneur dummy variable is zero in all cases where firm i in } \\
\text { period t is not linked to a scientist. As soon as a scientist joins firm i in period } \\
t \text {, the dummy variable takes the value } 1 \text { for the rest of the observed time } \\
\text { periods in our sample. }\end{array}$ \\
\hline$S T A R_{\mathrm{it}}$ & $\begin{array}{l}\text { Analogous to AE, but this dummy variable indicates whether the scientist } \\
\text { joining the firm can be seen as a star scientist according to his or her } \\
\text { accumulated academic research grants. }\end{array}$ \\
\hline VCafter & $\begin{array}{l}\text { Dummy variable indicating that the firm received its first round of venture } \\
\text { capital investment after its first SBIR award }\end{array}$ \\
\hline$S B I R \$_{i, t-1}$ & $\begin{array}{l}\text { Total SBIR grants in US\$ (phases } 1 \text { and } 2 \text { ) of firm } \mathrm{i} \text { in t- } 1 \text {. If a firm got more } \\
\text { than one grant per year, SBIR corresponds to the sum of all awards in this } \\
\text { time period. The US\$ are measured in constant } 1996 \text { prices. We used the NIH } \\
\text { price index for biomedical R\&D for the adjustment. }\end{array}$ \\
\hline Phase $1 \$$ i, $\mathrm{t}-1$ & Analogous to SBIR, but only phase 1 awards. \\
\hline Phase2\$ $\mathrm{i}, \mathrm{t}-1$ & Analogous to SBIR, but only phase 2 awards. \\
\hline$P 2_{\mathrm{i}, \mathrm{t}-1}$ & $\begin{array}{l}\text { Dummy indicating that firm i got a phase } 2 \text { award in period t- } 1 \\
{\left[\mathrm{D}\left(\text { Phase } 2 \$_{\mathrm{i}, \mathrm{t}-1}>0\right)\right] .} \\
\text { When } P 2 \text { is considered as endogenous variable, we use } P 2 \text { in period t instead } \\
\text { of its lagged value. }\end{array}$ \\
\hline$M A_{\mathrm{i}}$ & Dummy indicating that firm $\mathrm{i}$ is located in Massachusetts \\
\hline$C A_{\mathrm{i}}$ & Dummy indicating that firm $\mathrm{i}$ is located in California \\
\hline
\end{tabular}




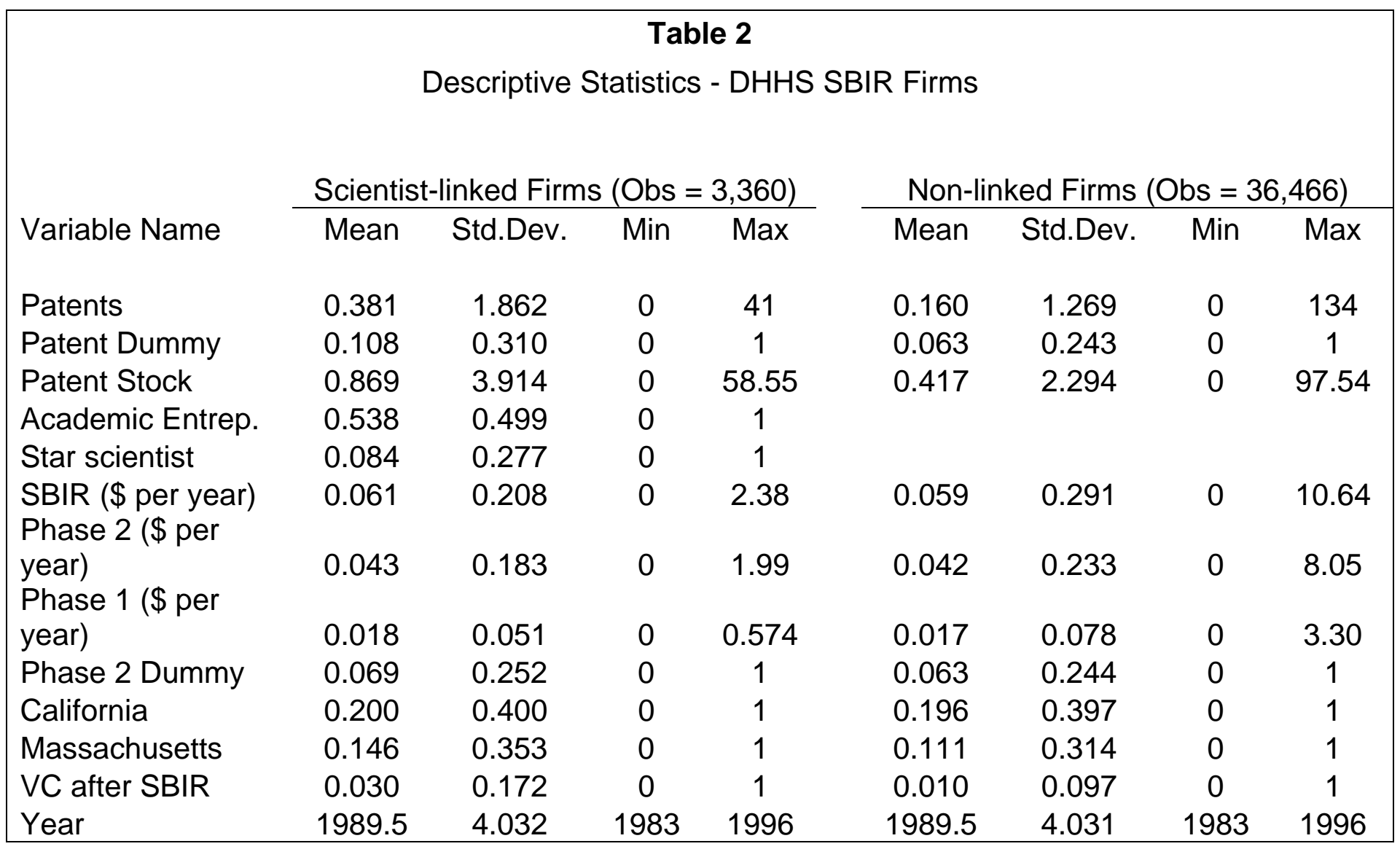




\section{Table 3}

\begin{tabular}{|c|c|c|c|c|}
\hline \multirow[b]{2}{*}{ Variables } & \multicolumn{4}{|c|}{ Dependent variable: star dummy } \\
\hline & A & B & C & D \\
\hline Academic Entrepreneur & $\begin{array}{c}0.193^{* \star} \\
(0.088)\end{array}$ & $\begin{array}{r}-0.057 \\
(0.105)\end{array}$ & $\begin{array}{r}-0.132 \\
(0.105)\end{array}$ & $\begin{array}{r}-0.166 \\
(0.106)\end{array}$ \\
\hline Researcher Years & & $\begin{array}{l}0.138 * * * \\
(0.001)\end{array}$ & $\begin{array}{l}0.138 \\
(0.001)\end{array}$ & $\begin{array}{l}0.133^{* * *} \\
(0.001)\end{array}$ \\
\hline Intercept & $\begin{array}{l}-1.282 \text { *** } \\
(0.006)\end{array}$ & $\begin{array}{l}-2.800 \text { *** } \\
(0.019)\end{array}$ & $\begin{array}{l}-2.852 \\
(0.019)\end{array}$ & $\begin{array}{l}-2.962 \text { *** } \\
(0.022)\end{array}$ \\
\hline $\begin{array}{l}\text { Test on joint } \\
\text { significance of } \\
\text { organization dummies: } \\
\chi^{2}(2)\end{array}$ & & & $246.31^{\star \star *}$ & $162.47^{\star \star \star}$ \\
\hline $\begin{array}{l}\text { Test on joint } \\
\text { significance of } \\
\text { field dummies: } \chi^{2}(17)\end{array}$ & & & & $739.90^{\star \star *}$ \\
\hline \# of obs. & 71802 & 71802 & 71802 & 71802 \\
\hline McFadden- $R^{2}$ & 0.0001 & 0.405 & 0.410 & 0.426 \\
\hline Log-Likelihood & -23341.05 & -13898.45 & -13779.39 & -13402.44 \\
\hline
\end{tabular}




\begin{tabular}{|c|c|c|}
\hline \multicolumn{3}{|c|}{ Table 4} \\
\hline & \multicolumn{2}{|c|}{ Dependent variable: VC after SBIR } \\
\hline Variables & $\mathrm{A}$ & $\mathrm{B}$ \\
\hline Academic Entrepreneur & $\begin{array}{l}0.539 \text { *** } \\
(0.061)\end{array}$ & $\begin{array}{l}0.541 \text { *** } \\
(0.062)\end{array}$ \\
\hline NIH Stars & $\begin{array}{l}0.320 * \star \star \\
(0.129)\end{array}$ & $\begin{array}{l}0.316 \text { *** } \\
(0.128)\end{array}$ \\
\hline Phase 2 dummy (t-1) & & $\begin{array}{l}0.287^{* \star *} \\
(0.066)\end{array}$ \\
\hline SBIR\$ (t-1) & & $\begin{array}{c}0.154 \text { *** } \\
(0.039)\end{array}$ \\
\hline Patent Stock (t-1) & $\begin{array}{l}0.027^{\star * *} \\
(0.004)\end{array}$ & $\begin{array}{l}0.024^{* * *} \\
(0.003)\end{array}$ \\
\hline Massachusetts & $\begin{array}{c}0.104 \text { * } \\
(0.060)\end{array}$ & $\begin{array}{r}0.043 \\
(0.062)\end{array}$ \\
\hline California & $\begin{array}{l}0.206 \text { *** } \\
(0.044)\end{array}$ & $\begin{array}{l}0.193 * * * \\
(0.045)\end{array}$ \\
\hline Intercept & $\begin{array}{l}-3.09 * \star \star \\
(0.108)\end{array}$ & $\begin{array}{l}-3.10^{\star \star \star} \\
(0.108)\end{array}$ \\
\hline $\begin{array}{l}\text { Joint Significance } \\
\text { Time Dummies: } \chi^{2}(11)\end{array}$ & $102.76^{\star \star \star}$ & $89.85^{\star \star \star}$ \\
\hline \# of obs. & 36982 & 36982 \\
\hline McFadden- $R^{2}$ & 0.077 & 0.093 \\
\hline Log-Likelihood & -2247.395 & -2209.844 \\
\hline
\end{tabular}




\begin{tabular}{|c|c|c|}
\hline \multicolumn{3}{|c|}{ Table 5} \\
\hline \multirow[b]{2}{*}{ Variables } & \multicolumn{2}{|c|}{ Dependent variable: Phase 2 Awarc } \\
\hline & A & B \\
\hline \multirow[t]{2}{*}{ Academic Entrepreneur } & $0.182 * \star \star$ & $0.135 * \star \star$ \\
\hline & $(0.045)$ & $(0.049)$ \\
\hline \multirow[t]{2}{*}{ NIH Star } & 0.057 & 0.101 \\
\hline & $(0.109)$ & $(0.113)$ \\
\hline \multirow[t]{2}{*}{ Phase 1 Dollars (t-1) } & & 6.668 *** \\
\hline & & $(0.247)$ \\
\hline \multirow[t]{2}{*}{ Patent Stock (t-1) } & $0.029 * * *$ & $0.014 * \star *$ \\
\hline & $(0.003)$ & $(0.003)$ \\
\hline \multirow[t]{2}{*}{ Massachusetts } & $.277 \star \star \star$ & $0.137 * \star *$ \\
\hline & $(0.030)$ & $(0.033)$ \\
\hline \multirow[t]{2}{*}{ California } & $0.057 * *$ & 0.022 \\
\hline & $(0.026)$ & $(0.028)$ \\
\hline \multirow[t]{2}{*}{ Intercept } & $-2.14 * \star \star$ & $-2.01 * \star *$ \\
\hline & $(0.044)$ & $(0.048)$ \\
\hline Joint Significance & $25427 * \star *$ & 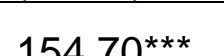 \\
\hline Time Dummies: $\chi^{2}(11)$ & $254.27^{n n}$ & $154.10^{n n}$ \\
\hline \# of obs. & 34137 & 34137 \\
\hline McFadden- $R^{2}$ & 0.030 & 0.161 \\
\hline Log-Likelihood & -8784.535 & -7599.329 \\
\hline
\end{tabular}




\begin{tabular}{|c|c|c|}
\hline \multicolumn{3}{|c|}{ Table 6} \\
\hline & $\begin{array}{c}\text { Dependent } \\
\text { variable: Patent } \\
\text { Dummy }\end{array}$ & $\begin{array}{c}\text { Dependent } \\
\text { variable: Number } \\
\text { of Patent } \\
\text { Applications }\end{array}$ \\
\hline Variables & A & B \\
\hline Academic Entrepreneur & $\begin{array}{l}0.253 \text { *** } \\
(0.050)\end{array}$ & $\begin{array}{l}0.769 \text { *** } \\
(0.094)\end{array}$ \\
\hline NIH Star & $\begin{array}{l}-0.055 \\
(0.116)\end{array}$ & $\begin{array}{l}-0.464 \text { * } \\
(0.246)\end{array}$ \\
\hline Phase 2 Dummy (t-1) & $\begin{array}{l}0.227 * \star \star \\
(0.069)\end{array}$ & $\begin{array}{l}0.401 \\
(0.112)\end{array}$ \\
\hline SBIR $\$(t-1)$ & $\begin{array}{l}0.180 \\
(0.080)\end{array}$ & $\begin{array}{l}0.293 * * * \\
(0.108)\end{array}$ \\
\hline Patent Stock (t-1) & $\begin{array}{l}0.279 * * \star \\
(0.012)\end{array}$ & $\begin{array}{l}0.464 * * * \\
(0.014)\end{array}$ \\
\hline Massachusetts & $\begin{array}{l}0.194^{* * *} \\
(0.032)\end{array}$ & $\begin{array}{l}0.394^{* * *} \\
(0.068)\end{array}$ \\
\hline California & $\begin{array}{c}0.171 \text { *** } \\
(0.027)\end{array}$ & $\begin{array}{l}0.520 \text { *** } \\
(0.054)\end{array}$ \\
\hline Intercept & $\begin{array}{l}-2.12 \text { *** } \\
(0.037)\end{array}$ & $\begin{array}{l}-3.502^{\star * \star} \\
(0.077)\end{array}$ \\
\hline $\begin{array}{l}\text { Joint Significance } \\
\text { Time Dummies: } \chi^{2}(12)\end{array}$ & $118.07^{\star \star \star}$ & $145.48^{\star \star *}$ \\
\hline \# of obs. & 39826 & 39826 \\
\hline McFadden- $R^{2}$ & 0.241 & 0.137 \\
\hline Log-Likelihood & -7432.141 & -12248.305 \\
\hline
\end{tabular}

